\title{
Prevalence of Methicillin Resistant Staphylococcal Bioaerosols in and around Residential Houses in an Urban Area in Central India
}

\author{
P. Kumar ${ }^{1,2}$ and A. K. Goel ${ }^{1}$ \\ ${ }^{1}$ Biotechnology Division, Defence Research \& Development Establishment, Gwalior 474002, India \\ ${ }^{2}$ Department of Microbiology, National Centre for Disease Control (NCDC), Delhi 110054, India \\ Correspondence should be addressed to A. K. Goel; akgoel73@yahoo.co.uk
}

Received 6 October 2015; Revised 26 December 2015; Accepted 28 December 2015

Academic Editor: Mariela Segura

Copyright (C) 2016 P. Kumar and A. K. Goel. This is an open access article distributed under the Creative Commons Attribution License, which permits unrestricted use, distribution, and reproduction in any medium, provided the original work is properly cited.

\begin{abstract}
Methicillin resistant staphylococci (MRS) commonly found in clinical samples or associated environment pose a major health challenge globally. The carriage rate of MRS in human population is high, especially in India but research on airborne distribution of MRS is scanty. The present study aimed to evaluate the prevalence of MRS in indoor and outdoor environment of residential houses. Air samples were collected using impactor air sampler. The total counts of viable bacteria, staphylococci, and MRS along with the particles of various sizes were determined from indoor and outdoor environment of 14 residential houses. MRS bacteria were identified as methicillin resistant S. aureus (MRSA) or coagulase negative staphylococci (CNS) employing biochemical and PCR assays. The average concentration of MRS inside and outside of the houses was $5.9 \%$ and $4.6 \%$ of the total bacteria, respectively. The maximum correlation of total indoor and outdoor bacteria with particulate matter was $10 \mu \mathrm{m}(r=0.74)$ and $5 \mu \mathrm{m}(r=0.84)$, respectively. Statistically, significant positive correlation of staphylococci and MRS was found with particles of 10-25 $\mu \mathrm{m}$ inside the houses. Molecular surveillance, antibiotic stewardship programme, and infection control policies can help to manage increasing MRS burden in developing countries.
\end{abstract}

\section{Introduction}

Bioaerosols and particulate matter of indoor and outdoor environment have a direct effect on the human health [1]. Bacteria have the diameter of about $2-8 \mu \mathrm{m}$ but these remain rarely free in the air. Generally, they tend to aggregate or attach to nonviable particles to form large clumps [2]. The total bacterial count is also significantly correlated with the number and size of particles $[3,4]$. Staphylococci are quite hardy, nonspore forming, and relatively heat resistant commensal bacteria that can survive longer on dry and inanimate surface in every environment in which humans coexist. Their prevalence in the bioaerosols of residential environment is of great concern.

Methicillin resistant staphylococci (MRS) including Staphylococcus aureus (MRSA) and coagulase negative staphylococci (MR-CNS) can cause superficial to deep life-threatening diseases even in healthy or immune-compromised individuals [5]. Initially, MRSA infections were generally hospital-acquired (HA-MRSA) affecting the persons directly associated with healthcare facilities due to high risk or weak immune systems. Subsequently, MRSA infection spread to healthy people who have not been hospitalized and such strains were called community-associated MRSA (CAMRSA). These are genetically distinguished from the HAMRSA and may cause rapidly progressive and fatal disease like necrotizing pneumonia, severe sepsis, and necrotizing fasciitis [6]. MRSA is evolving continuously and now the distinction between CA-MRSA and traditional HA-MRSA is blurring [7].

In previous studies in India, carriage rate of MRS and involvement of MRSA in nosocomial infection was found higher than USA [8-10]. The studies revealed that more than $50 \%$ of people were nasal carriers for $S$. aureus alone and out of them $3.89 \%$ were positive for MRSA [11, 12]. Airborne MRSA may cause infection but their transmission 
frequency is lower than transmission via direct contact [13]. However, the airborne transmission has been implicated in a number of nosocomial outbreaks of MRSA [14, 15]. In a previous study, we have detected MRS in bioaerosols during a trade fair at Gwalior, India [16]. Thus, a method for direct isolation and identification of airborne MRS is desirable for molecular surveillance of MRS in countries having higher prevalence of these bacteria. The present study aimed to optimize a protocol for direct isolation of airborne MRS and to study their distribution in atmosphere of residential houses at Gwalior, Central India. Several studies have used the methods of impaction on agar media. However, in this study, we have used the antibiotics for the direct selection of methicillin resistant staphylococci (MRS) for the first time. Other researchers have first isolated the strains and then subjected to antibiotic susceptibility testing. This procedure requires one additional day to confirm whether it is methicillin resistant or sensitive.

\section{Materials and Methods}

2.1. Sample Collection. A total of 14 residential houses located in 7 different colonies ( 2 houses from each colony) were selected for indoor and outdoor bacterial aerosol sampling from Gwalior, Central India (longitude $78^{\circ} 13^{\prime} \mathrm{E}$, latitude $\left.26^{\circ} 13^{\prime} \mathrm{N}\right)$. Those houses were selected from the city that had no adverse health issues and the inhabitants were neither healthcare worker nor hospitalized within the past 1 year. Air samples for microbiological analysis were collected using Reuter Centrifugal Sampler (Biotest, Germany) at a height of 1.5 meters from the surface to simulate human breathing zone.

The head of air sampler was disinfected with alcohol swabs before each air sampling and the sampler was turned on for $2 \mathrm{~min}$ prior to sampling to allow the alcohol to evaporate. Sterile media strips containing microbial content test agar (MCA) supplemented with cycloheximide $(100 \mu \mathrm{g} / \mathrm{mL})$, mannitol salt agar (MSA), and MSA containing $6 \mu \mathrm{g} / \mathrm{mL}$ methicillin were loaded into the disinfected air sampler. Air samples were collected for $2 \mathrm{~min}$ in duplicate from inside and outside of each house at a flow rate of $280 \mathrm{~L} / \mathrm{min}$ (the separation volume of the instrument was $40 \mathrm{~L} / \mathrm{min}$ ). MCA, MSA, and MSA containing methicillin were used for enumeration of total aerobic bacteria, staphylococci, and methicillin resistant staphylococci, respectively. The media strips were incubated at $35^{\circ} \mathrm{C}$ for 24 and $48 \mathrm{~h}$ to determine if the strips were overgrown. Air sampling results for cultivable bacteria were reported as colony forming units per cubic meter of air $\left(\mathrm{CFU} / \mathrm{m}^{3}\right)$ using the following formula:

$$
\begin{aligned}
& \mathrm{CFU} / \mathrm{m}^{3} \\
& =\frac{\text { Number of colonies on agar strip } \times 1000}{\text { separation volume } \times \text { sampling time in minutes }} .
\end{aligned}
$$

Thus, a maximum of 1062 colonies were present in the strip. Each strip contains 34 compartments or wells, which means each well contains 31 colonies $(1062 / 34=31)$.
2.2. Air Particulate Matter Measurement. Airborne particulate matter concentrations of six different sizes (aerodynamic diameter $0.3 \mu \mathrm{m}, 0.5 \mu \mathrm{m}, 1 \mu \mathrm{m}, 5 \mu \mathrm{m}, 10 \mu \mathrm{m}$, and $25 \mu \mathrm{m}$ ) were measured with commercial aerosol particle number counter (Lasair ll particle counter; Particle Measuring Systems, USA). Particles were counted in 4 sets (each set of $2 \mathrm{~min}$ ) with $2 \mathrm{~min}$ delay after every set. Both particle counter and RCS sampler were operated simultaneously.

2.3. Biochemical Identification of MRS. Five representative colonies of mannitol fermenting and nonfermenting bacteria from MSA containing methicillin from each house (indoor and outdoor) were cultured on brain heart infusion (BHI) agar. Presumptive MRSA were further screened for coagulase and thermonuclease production. A part of colony was emulsified in normal saline then mixed with rabbit plasma; clumping indicated positive result [17]. Colonies grown on $\mathrm{BHI}$ agar were further incubated for $2 \mathrm{~h}$ at $60^{\circ} \mathrm{C}$ and overlaid with thermonuclease agar and further incubated at $37^{\circ} \mathrm{C}$ till the development of pink zone around the positive control [18].

2.4. PCR Identification of MRS. The bacterial colonies were grown in LB broth for $18 \mathrm{~h}$. One $\mathrm{mL}$ of broth was centrifuged and the pellet was processed for DNA extraction using genomic DNA extraction kit as per the manufacturer instructions (MBI Fermentas, Vilnius, Lithuania). The amount and purity of the DNA were measured by spectrophotometer (NanoDrop-1000, Australia). A multiplex PCR was performed as described elsewhere, using the primers targeting a Staphylococcus specific region of the $16 \mathrm{~S} \mathrm{rDNA}$, S. aureus specific clf gene encoding a surface-associated fibrinogenbinding protein, and $m e c A$ gene, a primary determinant of methicillin-resistance in both $S$. aureus (MRSA) and coagulase negative staphylococci (MR-CNS) species $[19,20]$.

2.5. Antimicrobial Susceptibility Testing. All the MRS isolates were subjected to antibiotic susceptibility testing by disc diffusion method according to Clinical Laboratory Standards Institute guidelines [21]. Fresh cultures from tryptic soy agar plate were picked up and suspended in PBS and the turbidity of the tube was adjusted as the $0.5 \mathrm{MacFarland}$ standards. A $100 \mu \mathrm{L}$ of the suspension was swabbed evenly onto each Mueller-Hinton agar (MHA) plate (Difco laboratories, Sparks, MD). The agar surface was dried and the antibiotic discs were placed on the MHA surface using a sterile forceps. The disks were allowed to settle and the plates were incubated in inverted position at $37^{\circ} \mathrm{C}$ for $18-24 \mathrm{~h}$. Macrolide, lincosamide, and streptogramin B (MLS) resistance phenotype were determined by placing erythromycin disc $20 \mathrm{~mm}$ away from clindamycin disc. The test was conducted in duplicate for each isolate and the organisms giving the same resistance profile in both the plates were included in the study.

2.6. Statistical Analysis. The statistical analysis was carried out using SigmaPlot 2000. Indoor and outdoor total bacterial count and staphylococcal and MRS count were compared using paired $t$-test. Relationship between bacterial counts 
TABLE 1: Bacterial concentrations from inside and outside of residential houses at Gwalior.

\begin{tabular}{|c|c|c|c|c|c|c|c|c|c|}
\hline & \multicolumn{3}{|c|}{$\begin{array}{l}\text { Total bacteria } \\
\left(\mathrm{CFU} / \mathrm{m}^{3}\right)\end{array}$} & \multicolumn{3}{|c|}{$\begin{array}{l}\text { S. aureus } \\
\left(\mathrm{CFU} / \mathrm{m}^{3}\right)\end{array}$} & \multicolumn{3}{|c|}{$\begin{array}{l}\text { Methicillin resistant S. aureus } \\
\qquad\left(\mathrm{CFU} / \mathrm{m}^{3}\right)\end{array}$} \\
\hline & Indoor & Outdoor & In/out & Indoor & Outdoor & In/out & Indoor & Outdoor & In/out \\
\hline House 1 & 7088 & 5875 & 1.2 & 2050 & 1075 & 1.9 & 825 & 181.25 & 4.55 \\
\hline House 2 & 6275 & 5913 & 1.06 & 1575 & 1038 & 1.52 & 193.75 & 163.25 & 1.17 \\
\hline House 3 & 5650 & 4025 & 1.4 & 1475 & 1150 & 1.28 & 356.25 & 131.25 & 2.71 \\
\hline House 4 & 6925 & 1768 & 3.92 & 1225 & 700 & 1.75 & 275 & 87.5 & 3.14 \\
\hline House 5 & 7775 & 10175 & 0.76 & 1975 & 1713 & 1.15 & 662.5 & 400 & 1.66 \\
\hline House 6 & 7438 & 3950 & 1.88 & 1313 & 1100 & 1.19 & 275 & 212.5 & 1.29 \\
\hline House 7 & 12425 & 11013 & 1.13 & 3213 & 2350 & 1.37 & 881.25 & 618.75 & 1.42 \\
\hline House 8 & 11950 & 8900 & 1.34 & 2925 & 2313 & 1.26 & 1175 & 806 & 1.46 \\
\hline House 9 & 11275 & 13350 & 0.84 & 3050 & 3600 & 0.85 & 475 & 525 & 0.9 \\
\hline House 10 & 7375 & 8625 & 0.86 & 2568 & 3050 & 0.84 & 462.5 & 400 & 1.16 \\
\hline House 11 & 7413 & 6938 & 1.06 & 2825 & 2813 & 1 & 237.5 & 262.5 & 0.9 \\
\hline House 12 & 8725 & 6775 & 1.29 & 3475 & 1375 & 2.53 & 162.5 & 212.5 & 0.76 \\
\hline House 13 & 7175 & 6325 & 1.13 & 2575 & 3050 & 0.84 & 462.5 & 394 & 1.17 \\
\hline House 14 & 10413 & 10075 & 1.03 & 4125 & 3712.5 & 1.11 & 312.5 & 187.5 & 1.66 \\
\hline Average & $8421.5 \pm 2184.5$ & $7407.64 \pm 3142.4$ & 1.35 & $2454.92 \pm 880.96$ & $2074.25 \pm 1037$ & 1.18 & $495.68 \pm 299.47$ & $338.04 \pm 208.01$ & $1.71^{* *}$ \\
\hline$P$ value $(95 \%)$ & & $>0.5$ & & $P>$ & & & $P<$ & 0.01 & \\
\hline
\end{tabular}

${ }^{* *}$ Significant difference in indoor and outdoor MRS concentration $(P<0.01)$.

and particle number was examined by Spearman correlation analysis.

\section{Results and Discussion}

3.1. Indoor and Outdoor Concentration of Bioaerosols (Bacteria, Staphylococci, and MRS). The total bacterial concentrations inside the residential homes varied in the range of 5650 to $12425 \mathrm{CFU} / \mathrm{m}^{3}(8420.5 \pm 2183.5)$. The outdoor total bacterial concentration ranged from 1775 to $13350 \mathrm{CFU} / \mathrm{m}^{3}$ $(7405.4 \pm 3142.4)$. The average indoor/outdoor (I/O) ratio was found to be 1.35 (Table 1). The difference between mean of indoor and that of outdoor total bacteria was nonsignificant $(P>0.05)$. Staphylococci concentration for indoor residential homes was found in the range of 1225 to $4125 \mathrm{CFU} / \mathrm{m}^{3}$ (2454.9 \pm 880.96$)$. Outdoor total bacterial concentration ranged from 700 to $2713 \mathrm{CFU} / \mathrm{m}^{3}(2074.3 \pm$ 1037). The average $\mathrm{I} / \mathrm{O}$ ratio was found to be 1.18 . The difference between mean concentration of indoor and that of outdoor staphylococci was nonsignificant $(P>0.05)$. MRS concentration for indoor residential homes was found in the range of $162.5 \mathrm{CFU} / \mathrm{m}^{3}$ to $1175 \mathrm{CFU} / \mathrm{m}^{3}$ (495.7 \pm 299.5$)$. This was $5.9 \%$ of the total bacterial concentration. Outdoor total bacterial concentration ranged from $87.5 \mathrm{CFU} / \mathrm{m}^{3}$ to $806 \mathrm{CFU} / \mathrm{m}^{3}(338.03 \pm 208.01)$ which was $4.6 \%$ of the total bacterial concentration. The average $\mathrm{I} / \mathrm{O}$ ratio was found to be 1.7. The difference between mean indoor and outdoor concentration of MRS was statistically significant $(P<0.01$, paired $t$-test) (Table 1$)$.

The average concentration of airborne MRS was significantly higher inside the residential houses than outdoor environment (Table 1). The average concentration of staphylococci and total viable bacteria was also higher inside the residential homes but the differences between indoor and outdoor concentrations were statistically nonsignificant. The main contributor of indoor viable bacterial concentration is human activities including rafting, desquamated skin scales, and dry fabrics $[4,22]$. Bed-making activities also liberate significantly higher concentration of MRSA in the air [23]. $S$. epidermidis is a constituent of commensal microflora of the human skin and it is believed that pedestrians skin flora also contribute the elevated airborne staphylococcal concentration.

3.2. Correlation of Indoor and Outdoor Bioaerosols with Particulate Matter Size. Under indoor conditions, a significant positive correlation of total bacteria was found with particle size of $10 \mu \mathrm{m}$ (Spearman $r=0.74)$, followed by $5 \mu \mathrm{m}(r=0.6)$ (Table 2). Significant correlation of staphylococci was found with particles of $10 \mu \mathrm{m}(r=0.73)$, followed by $25 \mu \mathrm{m}(r=$ $0.59)$. However, MRS were correlated with particles of $25 \mu \mathrm{m}$ $(r=0.69)$, followed by $10 \mu \mathrm{m}(r=0.54)$. Under outdoor conditions, the significant correlation of total bacteria was found with particles of size of $5 \mu \mathrm{m}(r=0.84)$, followed by $10 \mu \mathrm{m}(r=0.79), 1 \mu \mathrm{m}(r=0.74)$, and $25 \mu \mathrm{m}(r=$ $0.64)$. Significant correlation of staphylococci was found with particles of $1 \mu \mathrm{m}(r=0.72)$, followed by $5 \mu \mathrm{m}(r=0.68)$, $0.5 \mu \mathrm{m}(r=0.6)$, and $10 \mu \mathrm{m}(r=0.6)$, whereas MRS were maximally correlated with particles of $10 \mu \mathrm{m}(r=0.69)$, followed by $5 \mu \mathrm{m}(r=0.78)$ and $25 \mu \mathrm{m}(r=0.65)$.

The viable bacteria in air tend to aggregate and exist on large particles [2]. Staphylococci present in the indoor air are generally attached to desquamated skin scales and have the diameter range of 4-20 $\mu \mathrm{m}$. Skin fragments dispersed through the woven fabrics have a median size of $20 \mu \mathrm{m}$ [24]. In another study of bacteria recovered from skin fragments, 
TABLE 2: Correlation between bacteria and particle size.

\begin{tabular}{lccccccc}
\hline \multirow{2}{*}{ Correlation (Spearman $r$ ) } & & \multicolumn{5}{c}{ Particle size $\left(\right.$ number $\left./ \mathrm{m}^{3}\right)$} \\
& & $0.3 \mu \mathrm{m}$ & $0.5 \mu \mathrm{m}$ & $1 \mu \mathrm{m}$ & $5 \mu \mathrm{m}$ & $10 \mu \mathrm{m}$ & $25 \mu \mathrm{m}$ \\
\hline \multirow{3}{*}{ Indoor } & Total bacteria & -0.2967 & 0.09451 & 0.2352 & $0.6^{*}$ & $0.736^{* *}$ & 0.4664 \\
& Staphylococci & -0.2923 & 0.1516 & 0.244 & 0.4989 & $0.7319^{* *}$ & $0.5919^{*}$ \\
& MRS & -0.207 & -0.2885 & 0.3216 & 0.4912 & $0.5352^{*}$ & $0.6891^{* *}$ \\
\hline \multirow{3}{*}{ Outdoor } & Total bacteria & -0.5297 & 0.2264 & $0.7363^{* *}$ & $0.8374^{* * *}$ & $0.7934^{* * *}$ & $0.644^{*}$ \\
& Staphylococci & -0.4224 & $0.6008^{*}$ & $0.7217^{* *}$ & $0.677^{* *}$ & $0.5985^{*}$ & 0.33 \\
& MRS & -0.4361 & 0.1718 & 0.5176 & $0.7753^{*}$ & $0.8261^{* * *}$ & $0.6542^{*}$ \\
\hline
\end{tabular}

$*(P \leq 0.05)$.

${ }^{* *}(P \leq 0.01)$.

${ }^{* * *}(P \leq 0.001)$

$48 \%$ of bacteria were of $8.2 \mu \mathrm{m}$ or larger [25]. The significant positive correlations of indoor staphylococci including MRS with $10-25 \mu \mathrm{m}$ of particle in our results indicate the association of these bacteria with skin and nasal carriers (Table 2). The total indoor bacterial concentration was significantly correlated with particles $5-10 \mu \mathrm{m}$ in size. S. aureus on airborne particles have shown an average of four viable organisms per particle with a mean equivalent diameter of $14 \mu \mathrm{m}$ [24, 26]. Sneezing and coughing are also important sources of bioaerosols. In a study of relationship between viable bacteria and particle size, bacteria of $>7.5 \mu \mathrm{m}$ correlated with exhaled carbon dioxide indicating nasal carriers [4]. Bacteria of size between 3 and $7.5 \mu \mathrm{m}$ (in tracheal and bronchial regions) remain in clumps whereas bacteria in the size range of $1-2 \mu \mathrm{m}$ (terminal bronchial region) remain free [4]. Our previous studies demonstrated a significant rise in airborne microbes including MRS during human gathering or anthropogenic activities in urban environment [16].

3.3. Multiplex PCR for Identification of MRS and Their Antibiotic Resistance Pattern. The presumptive MRS strains selected from methicillin containing MSA strips were found to be PCR positive for staphylococci specific $16 \mathrm{~S} \mathrm{rDNA}$ gene. Out of them, 94\% strains were found positive for mecA gene (Figure 1) and the remaining strains were observed to be PCR negative for mecA gene cassettes but were able to grow on methicillin concentration more than MIC. Among MRS, 9.5\% of strains harbored clf gene specific for S. aureus.

A total of $87.4 \%$ of $m e c A$ positive (MRS) strains were found to be multidrug resistant (resistance for more than two different classes of antibiotics). MLS resistance phenotypes were found in $27.4 \%$ of strains including $16.7 \%$ of inducible expression (iMLS) and $10.7 \%$ of constitutive (cMLS) expression phenotype. The $\mathrm{M}$ resistance phenotype (resistance to erythromycin but not to lincosamides or streptogramins) was found only in $6(7.1 \%)$ strains. Among the other antibiotics, $47.6 \%$ of strains were observed to be resistant to sulfamethoxazole-trimethoprim, $42.9 \%$ to quinolones, $8.3 \%$ to gentamicin, and $7.1 \%$ to mupirocin and $4.8 \%$ of strains were found to have intermediate resistance to tetracycline. All the MRS strains were found to be susceptible to linezolid and vancomycin.
MRS infections, including MRSA, occur most frequently among persons in hospitals and healthcare facilities who are at high risk or have weakened immune systems. Now CAMRSA (USA300) has started replacing traditional MRSA (healthcare associated) in hospitals on a large scale and become dangerous epidemic strain worldwide [27]. The main objectives of this study were to optimize a methodology for direct isolation of airborne MRS and to determine their distribution pattern. Isolation of bioaerosols followed by their identification to genus (staphylococci) or species level and screening for the presence of antibiotic resistant determinant ( $m e c A$ genotype) is a time consuming activity. In our previous report we did isolation of bacterial bioaerosols followed by their identification and characterization for mecA genotype which was labor intensive and required additional time [16]. Therefore, a direct method for isolation of airborne MRS is utmost important to complete a timely surveillance program.

MRS are well known as nasal colonizer in normal community and the colonization of virulent MRSA is significantly high $[28,29]$. Airborne MRS may infect a person in two ways either by inhalation or by settling directly onto susceptible area, such as a wound [24]. MRS infections are important concern for health authorities and researchers across the world as it caused an approximate threefold increase in direct cost and prolonged hospital stay in comparison to infections due to methicillin sensitive staphylococci [30]. Infection of multidrug resistant MRS makes treatment very difficult because the drug of choice relies on newer generations of medicine which may be neither cost effective nor easily available to local market. Inappropriate and inadequate practices like misuse, abuse, and overprescription of antibiotics also result in the development of multidrug resistance [31]. Penicillin, cephalosporin, cotrimoxazole, and quinolones cover most of the antimicrobials prescribed in India [32]. Penicillin, cephalosporin, and quinolones are DNA damaging agents and can stimulate the drug resistance via SOS independent manner and through the induction of RecA-mediated repair, an error prone repair mechanism that induces mutations [33]. This repair accumulates various mutations which can lead to evolution in drug resistance.

Thus, the study confirmed that airborne MRS are commonly present in indoor and outdoor environment of the residential houses. Their concentration is significantly higher 


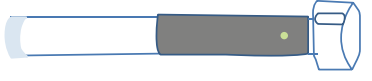

(A) Air sampling

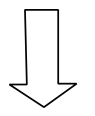

(B) Culture on mannitol salt agar + methicillin $(6 \mu \mathrm{g} / \mathrm{mL})$

(C) Biochemical assays
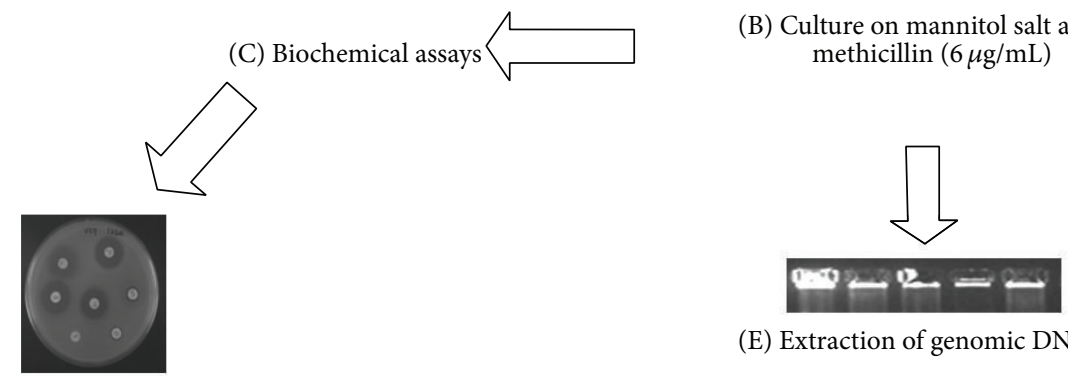

(E) Extraction of genomic DNA

(D) Screening of antibiotic resistant phenotype
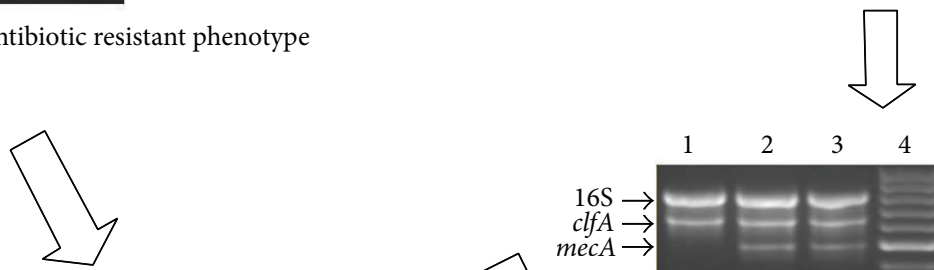

(G) Comparison of phenotype and genotype

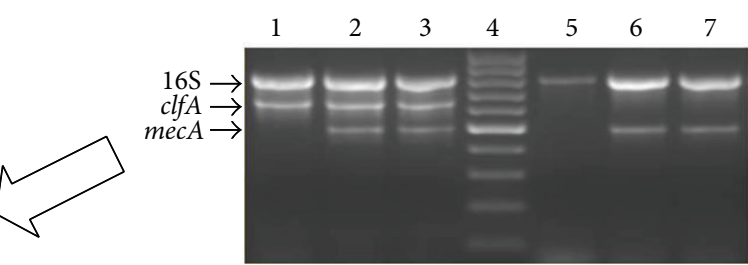

(F) Amplification of staphylococci

specific $16 \mathrm{~S}$ rDNA, clfA, and mecA

FIGURE 1: Flow diagram for isolation of MRS bioaerosols from residential houses. (F) Multiplex PCR for the detection of mecA gene in staphylococci. Lane 1: S. aureus ATCC 25923, lane 2: MRS isolate AMR 911, lane 3: MRS isolate AMR 927, lane 4: 100 bp ladder, lane 5: S. epidermidis ATCC 12228, lane 6: MRS isolate AMR 901, and lane 7: MRS isolate AMR 904.

inside the houses as compared to the outdoor environment. Molecular surveillance, antibiotic stewardship programme, and infection control policies can help to manage increasing MRS burden in developing countries.

\section{Conflict of Interests}

The authors declare that there is no conflict of interests regarding the publication of this paper.

\section{Acknowledgments}

The authors thank Director, DRDE, Gwalior for providing necessary facilities and financial support for the work. P. Kumar thanks Council of Scientific \& Industrial Research (CSIR), New Delhi, for providing Senior Research Fellowship.

\section{References}

[1] R. Williams, J. Suggs, R. Zweidinger et al., “The 1998 Baltimore Particulate Matter Epidemiology-Exposure Study. Part 1. Comparison of ambient, residential outdoor, indoor and apartment particulate matter monitoring," Journal of Exposure Analysis and Environmental Epidemiology, vol. 10, no. 6, pp. 518-532, 2000.

[2] B. L. Jones and J. T. Cookson, "Natural atmospheric microbial conditions in a typical suburban area," Applied and Environmental Microbiology, vol. 45, no. 3, pp. 919-934, 1983.

[3] G. S. Oxborrow, N. D. Fields, J. R. Puleo, and C. M. Herring, "Quantitative relationship between airborne viable and total particles," Health Laboratory Science, vol. 12, no. 1, pp. 47-51, 1975.

[4] K. W. Tham and M. S. Zuraimi, "Size relationship between airborne viable bacteria and particles in a controlled indoor environment study," Indoor Air, vol. 15, no. 9, pp. 48-57, 2005.

[5] D. J. Anderson, D. J. Sexton, Z. A. Kanafani, G. Auten, and K. S. Kaye, "Severe surgical site infection in community hospitals: epidemiology, key procedures, and the changing prevalence of methicillin-resistant Staphylococcus aureus," Infection Control and Hospital Epidemiology, vol. 28, no. 9, pp. 1047-1053, 2007.

[6] S. Boyle-Vavra and R. S. Daum, "Community-acquired methicillin-resistant Staphylococcus aureus: the role of PantonValentine leukocidin," Laboratory Investigation, vol. 87, no. 1 , pp. 3-9, 2007.

[7] R. H. Deurenberg and E. E. Stobberingh, "The molecular evolution of hospital- and community-associated methicillinresistant Staphylococcus aureus," Current Molecular Medicine, vol. 9, no. 2, pp. 100-115, 2009. 
[8] S. L. Kaplan, K. G. Hulten, B. E. Gonzalez et al., “Threeyear surveillance of community-acquired Staphylococcus aureus infections in children," Clinical Infectious Diseases, vol. 40, no. 12, pp. 1785-1791, 2005.

[9] S. Saxena, K. Singh, and V. Talwar, "Methicillin-resistant Staphylococcus aureus prevalence in community in the East Delhi area," Japanese Journal of Infectious Diseases, vol. 56, no. 2, pp. 54-56, 2003.

[10] B. Shrestha, B. M. Pokhrel, and T. M. Mohapatra, "Phenotypic characterization of nosocomial isolates of Staphylococcus aureus with reference to MRSA," Journal of Infection in Developing Countries, vol. 3, no. 7, pp. 554-560, 2009.

[11] S. S. Chatterjee, P. Ray, A. Aggarwal, A. Das, and M. Sharma, "A community-based study on nasal carriage of Staphylococcus aureus," Indian Journal of Medical Research, vol. 130, no. 6, pp. 742-748, 2009.

[12] A. G. Mainous III, W. J. Hueston, C. J. Everett, and V. A. Diaz, "Nasal carriage of Staphylococcus aureus and methicillinresistant $S$ aureus in the United States, 2001-2002," Annals of Family Medicine, vol. 4, no. 2, pp. 132-137, 2006.

[13] C. O. Solberg, "Spread of Staphylococcus aureus in hospitals: causes and prevention," Scandinavian Journal of Infectious Diseases, vol. 32, no. 6, pp. 587-595, 2000.

[14] E. A. Mortimer Jr., E. Wolinsky, A. J. Gonzaga, and C. H. Rammelkamp Jr., "Role of airborne transmission in staphylococcal infections," British Medical Journal, vol. 1, no. 5483, pp. 319-322, 1966.

[15] D. N. P. Kumari, T. C. Haji, V. Keer, P. M. Hawkey, V. Duncanson, and E. Flower, "Ventilation grilles as a potential source of methicillin-resistant Staphylococcus aureus causing an outbreak in an orthopaedic ward at a district general hospital," Journal of Hospital Infection, vol. 39, no. 2, pp. 127-133, 1998.

[16] J. Yadav, A. Kumar, P. Mahor et al., "Distribution of airborne microbes and antibiotic susceptibility pattern of bacteria during Gwalior trade fair, Central India," Journal of the Formosan Medical Association, vol. 114, pp. 639-646, 2015.

[17] M. Tager and M. C. Drummond, "Staphylocoagulase," Annals of the New York Academy of Sciences, vol. 128, no. 1, pp. 92-111, 1965.

[18] R. V. Lachica, "Simplified thermonuclease test for rapid identification of Staphylococcus aureus recovered on agar media," Applied and Environmental Microbiology, vol. 32, no. 4, pp. 633634, 1976.

[19] W. J. Mason, J. S. Blevins, K. Beenken, N. Wibowo, N. Ojha, and M. S. Smeltzer, "Multiplex PCR protocol for the diagnosis of staphylococcal infection," Journal of Clinical Microbiology, vol. 39, no. 9, pp. 3332-3338, 2001.

[20] D. J. Geha, J. R. Uhl, C. A. Gustaferro, and D. H. Persing, "Multiplex PCR for identification of methicillin-resistant staphylococci in the clinical laboratory," Journal of Clinical Microbiology, vol. 32, no. 7, pp. 1768-1772, 1994.

[21] CLSI, "Performance standards for antimicrobial susceptibility testing, twenty second informational supplement," CLSI Document M100-S22, Clinical and Laboratory Standards Institute (CLSI), Wayne, Pa, USA, 2012.

[22] K. Roberts, A. Hathway, L. A. Fletcher, C. B. Beggs, M. W. Elliott, and P. A. Sleigh, "Bioaerosol production on a respiratory ward," Indoor and Built Environment, vol. 15, no. 1, pp. 35-40, 2006.

[23] T. Shiomori, H. Miyamoto, K. Makishima et al., "Evaluation of bedmaking-related airborne and surface methicillin-resistant Staphylococcus aureus contamination," Journal of Hospital Infection, vol. 50, no. 1, pp. 30-35, 2002.
[24] C. A. Mackintosh, O. M. Lidwell, A. G. Towers, and R. R. Marples, "The dimensions of skin fragments dispersed into the air during activity," Journal of Hygiene, vol. 81, no. 3, pp. 471-479, 1978.

[25] I. M. Lundholm, "Comparison of methods for quantitative determinations of airborne bacteria and evaluation of total viable counts," Applied and Environmental Microbiology, vol. 44, no. 1, pp. 179-183, 1982.

[26] O. M. Lidwell, W. C. Noble, and G. W. Dolphin, "The use of radiation to estimate the numbers of micro-organisms in airborne particles," The Journal of Hygiene, vol. 57, pp. 299-308, 1959.

[27] M. Otto, "Community-associated MRSA: a dangerous epidemic," Future Microbiology, vol. 2, no. 5, pp. 457-459, 2007.

[28] R. M. Klevens, M. A. Morrison, J. Nadle et al., "Invasive methicillin-resistant Staphylococcus aureus infections in the United States," Journal of the American Medical Association, vol. 298, no. 15, pp. 1763-1771, 2007.

[29] F. C. Tenover, S. McAllister, G. Fosheim et al., "Characterization of Staphylococcus aureus isolates from nasal cultures collected from individuals in the United States in 2001 to 2004," Journal of Clinical Microbiology, vol. 46, no. 9, pp. 2837-2841, 2008.

[30] M. A. Abramson and D. J. Sexton, "Nosocomial methicillinresistant and methicillin-susceptible Staphylococcus aureus primary bacteremia: at what costs?" Infection Control and Hospital Epidemiology, vol. 20, no. 6, pp. 408-411, 1999.

[31] V. Lakshmi, "Need for national/regional guidelines and policies in India to combat antibiotic resistance," Indian Journal of Medical Microbiology, vol. 26, no. 2, pp. 105-107, 2008.

[32] K. S. K. India, S. J. Chandy, L. Jeyaseelan, R. Kumar, and S. Suresh, "Antimicrobial prescription patterns for common acute infections in some rural \& urban health facilities of India," Indian Journal of Medical Research, vol. 128, no. 2, pp. 165-171, 2008.

[33] E. López, M. Elez, I. Matic, and J. Blázquez, "Antibiotic-mediated recombination: ciprofloxacin stimulates SOS-independent recombination of divergent sequences in Escherichia coli," Molecular Microbiology, vol. 64, no. 1, pp. 83-93, 2007. 


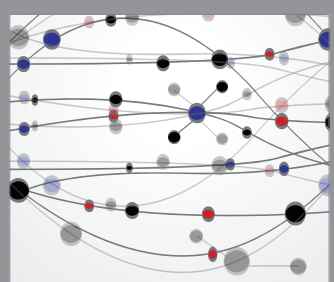

The Scientific World Journal
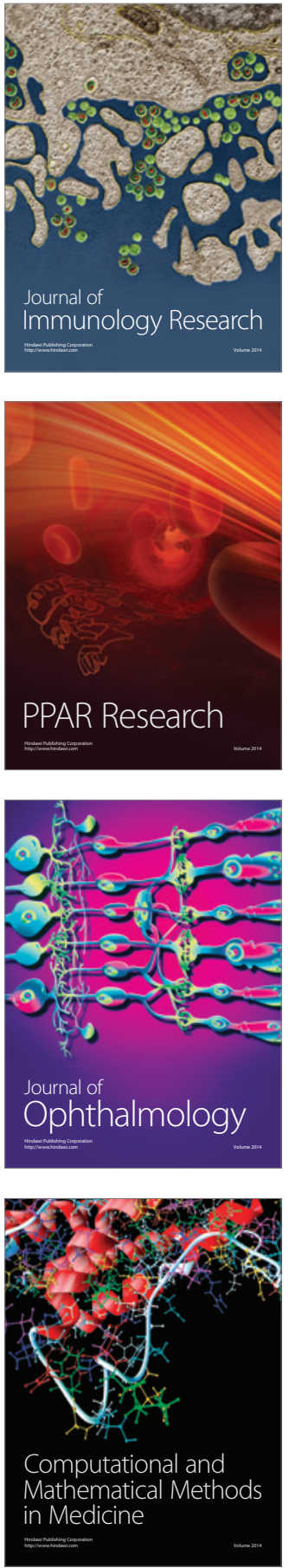

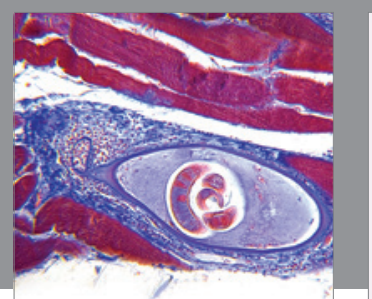

Gastroenterology Research and Practice

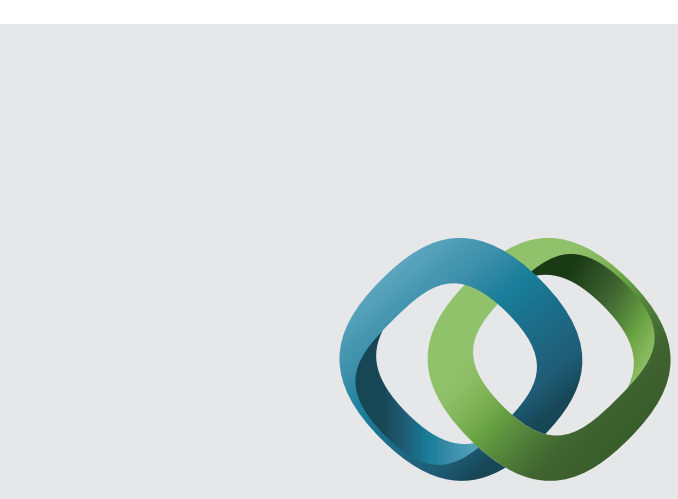

\section{Hindawi}

Submit your manuscripts at

http://www.hindawi.com
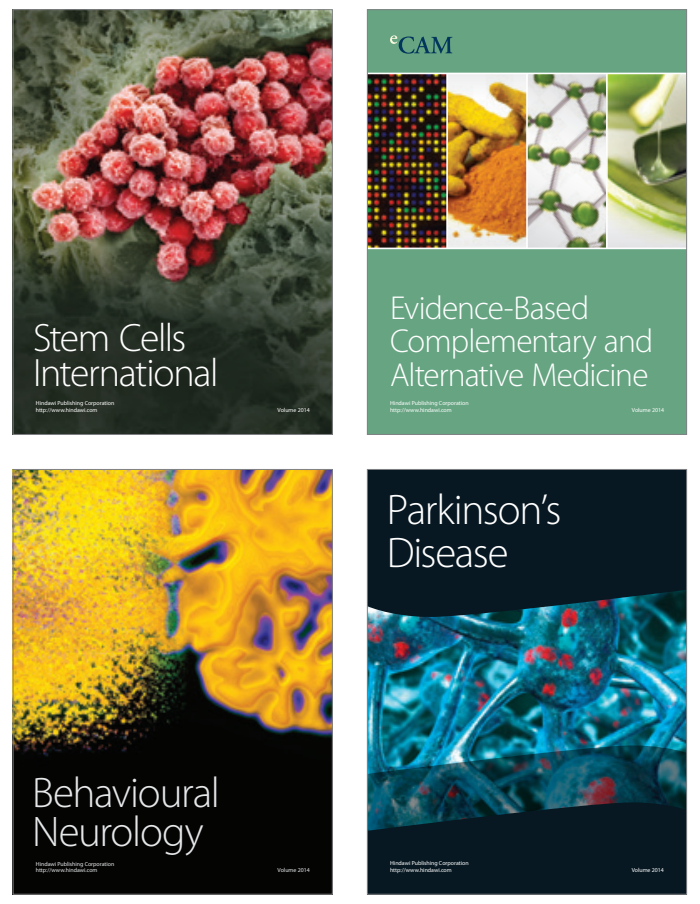
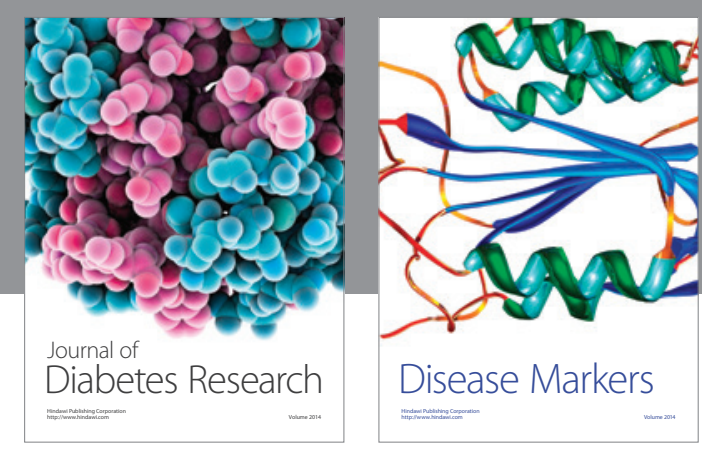

Disease Markers
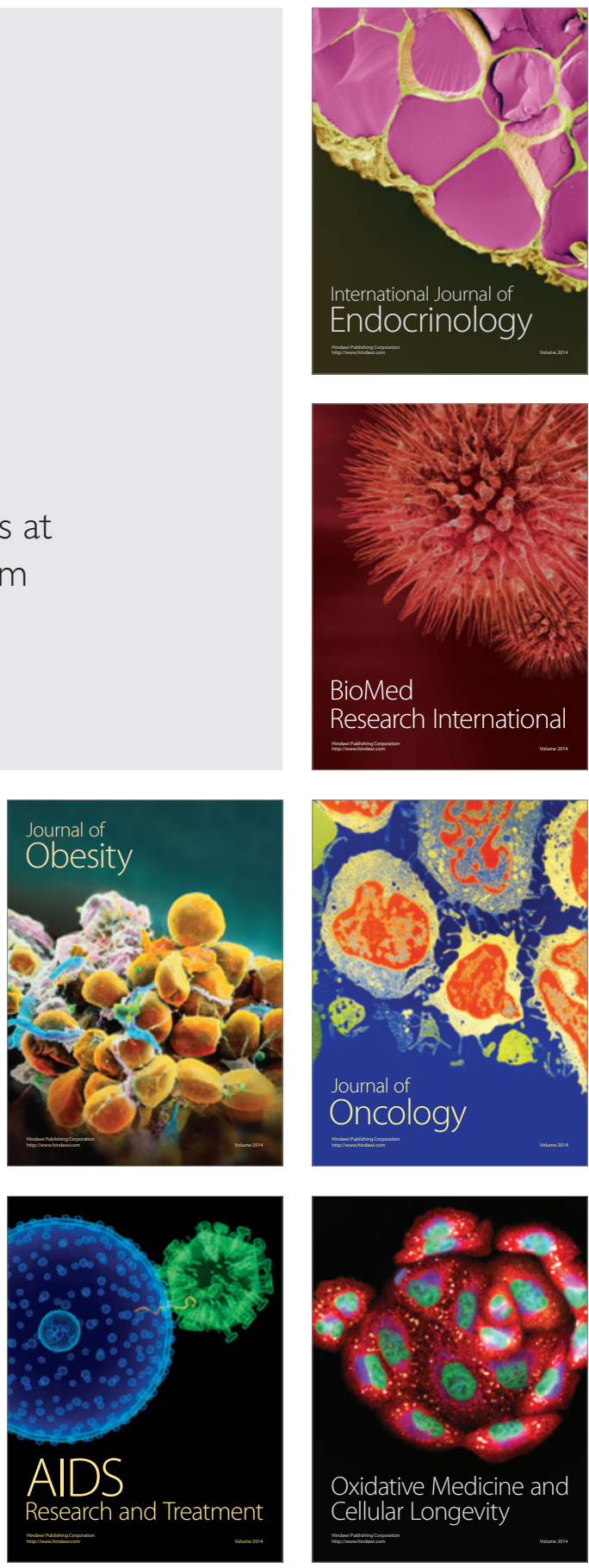